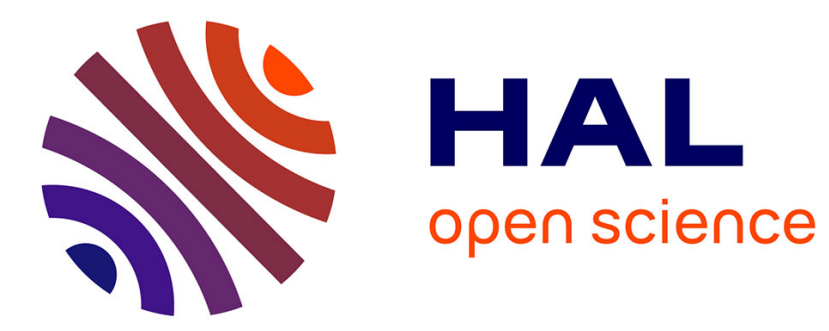

\title{
NATIONAL CEREMONIES: THE PURSUIT OF AUTHENTICITY
}

Gordana Uzelac

\section{To cite this version:}

Gordana Uzelac. NATIONAL CEREMONIES: THE PURSUIT OF AUTHENTICITY. Ethnic and Racial Studies, 2010, PP (PP), pp.1. 10.1080/01419871003703243 . hal-00589481

\section{HAL Id: hal-00589481 \\ https://hal.science/hal-00589481}

Submitted on 29 Apr 2011

HAL is a multi-disciplinary open access archive for the deposit and dissemination of scientific research documents, whether they are published or not. The documents may come from teaching and research institutions in France or abroad, or from public or private research centers.
L'archive ouverte pluridisciplinaire HAL, est destinée au dépôt et à la diffusion de documents scientifiques de niveau recherche, publiés ou non, émanant des établissements d'enseignement et de recherche français ou étrangers, des laboratoires publics ou privés. 


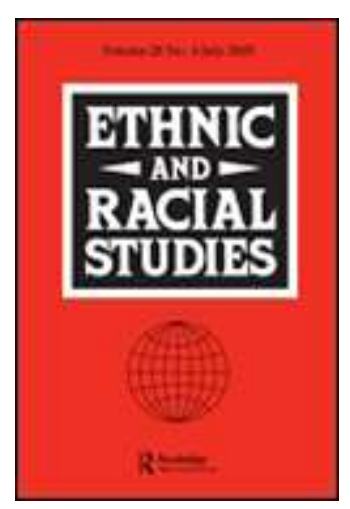

\section{NATIONAL CEREMONIES: THE PURSUIT OF AUTHENTICITY}

\begin{tabular}{|r|l|}
\hline Journal: & Ethnic and Racial Studies \\
\hline Manuscript ID: & RERS-2009-0015.R2 \\
\hline Manuscript Type: & Original Manuscript \\
\hline Keywords: & $\begin{array}{l}\text { national ceremonies, authenticity, Nationalism, rituals, } \\
\text { performances, national culture }\end{array}$ \\
\hline
\end{tabular}

\section{ScholarONE \\ Manuscript Central}




\begin{abstract}
:
This article asks what, if any, impact national ceremonies have on the formation of national identities. Why are some ceremonies perceived as national and persistent through time, while others fail to achieve that status? It argues that national ceremonies can only be examined as specific types of situations - performances, rather than rituals - characterized by the relationship between performers and their audiences. Following Jeffery Alexander's cultural pragmatics theory, national ceremonies are seen as successful only when a performance is perceived as authentic. A ceremony's authenticity is, at best, a quality of experience among its audience. Only when the audience is transformed into willing participants through a performance's mise-en-scène can a national ceremony be seen as a ritual-like performance. The paper will conclude that the efficacy of these performances is temporary, and that even when a performance succeeds in creating a community of shared experience, that community dissolves with the end of the performance.
\end{abstract}

Key words: national ceremonies, authenticity, rituals, performances, nationalism, national identity 


\section{NATIONAL CEREMONIES:}

\section{THE PURSUIT OF AUTHENTICITY}

On 30 January 2008 I reconstructed my identity. In a grandiose ceremony I 'solemnly, sincerely and truly declared and affirm[ed] that on becoming a British citizen, I w[ould] be faithful and bear true allegiance to Her Majesty Queen Elizabeth the Second, her Heirs and Successors, according to law'. It was the pinnacle of an elevenyear-long preparation. Thanks to the 145 page-long second edition of the official Home Office manual on Life in the $U K$, I am now the proud possessor of a certificate attesting to my knowledge of the subject. I have seen the Remembrance ceremony, worn a poppy, watched the Queen's opening of Parliament, had a few glimpses of the Trooping of the Colours, watched the Queen's Golden Jubilee, and thoroughly enjoyed (from a professional point of view) many last nights of the Proms. According to some theories of nations and nationalism, participation in these ceremonies is supposed to instil in me a sense of an authentic British identity and open the gates to the eternal well of British collective memory.

This paper will argue against such an understanding of the role of national ceremonies. While it will not be denied that ceremonies can exercise potentially transformative power, this paper will demonstrate that all national ceremonies have to be observed as performances rather than rituals, characterized by the specific relationship between their performers and audiences. The transformative power of these performances will only be felt if the audience perceives the performance as authentic, which this analysis will understand as a quality of experience. This will be 
set against other attempts to objectify the notion of the authentic - so visible in all nationalist ideologies. The paper will conclude that even when a performance succeeds in creating a community of shared experience, that community dissolves with the end of the performance.

\section{National Ceremonies}

The author most responsible for viewing national ceremonies as vehicles for national identity is George L. Mosse. The emergence, function, and structure of national ceremonies are most thoroughly examined in his book The Nationalisation of the Masses (1975). In essence, Mosse adopts a Durkheimian approach in which national ceremonies are seen as social facts and can therefore be explained as providers for the objectification of the general will (1975: 2). These ceremonies were part and parcel of the 'new politics' of secular religion whereby the people worshipped themselves. Based on the idea of popular sovereignty, they transformed, according to Mosse, 'the chaotic crowd of the "people" into a mass movement' which 'shared a belief in popular unity through a national mystique' (ibid.). Political action now became a 'drama supposedly shared by the people themselves' (ibid., emphasis added). The developed discourse of secular religion is the main framework through which Mosse analyses the role of national ceremonies and public festivals, which are seen as rituals that are structured by a specific liturgy and that convey a clearly defined cult to the faceless masses. They are enacted on sacred sites and surrounded by sacred symbols that apparently objectify national myths. Indeed, phrased like this, national ceremonies cannot but be seen as vehicles of secular religion. These carefully structured ceremonies and festivals have a specific function. Mosse traces their origin to Rousseau's recommendations to the Polish government, where he suggests that the 
Poles will, through patriotic festivals, 'become imbued with the virtue of patriotism' (ibid.: 73). Mosse concludes: 'Public festivals were designed not merely to further the enthusiasms of crowds, but also to form them through the use of an orderly liturgy' (ibid.).

Three main structural elements of these rituals are emphasised in Mosse's framework: the producers of the ceremony, the form of the so-called liturgy, and the recipient masses. Mosse spends considerable space in his book describing the producers, mainly the cultural and political elite acting as individuals and organisations. $\mathrm{He}$ carefully describes the form of the liturgy and explains how a cultural background conditions the elite's choices in their creative work. The masses are mainly described as participants that take an active role in enacting the liturgy - from the dress they wear to the banners they carry and the songs they sing. The fact that these masses actively participate in the rite is seen as necessary and sufficient evidence of their being 'imbued' with the virtues of patriotism. Thus defined, national rituals have been adopted by many theories of nationalism that stress the importance of such ceremonies in the shaping of national identities or national collective memory. Different perceptions of the roles and functions of national rituals distinguish some of the dominant approaches to the process of nation-formation. Those that emphasise the creative role of the producers we see as constructivist, and those that emphasise the constraining effect of cultural background as ethno-symbolist. Yet in both approaches the emphasis is on the interaction between, in Mosse's words, the producers of the rite and the liturgy they create. 
However, the structure and function of national ceremonies are not so unproblematic, even in Mosse's work. On the one hand, Mosse projects an image of these ceremonies as fixed, uncontested, protected and preserved occurrences. After all, the language of rituals, rites, liturgy and cult implies these attributes, especially in reference to Mosse's favourite parallel example of Christian rites and liturgies. Yet, as we know, changes in Christian liturgy historically led to religious schisms, and were therefore only rarely sanctioned by the highest church authorities. Does national liturgy have the same status of fixity?

Toward the end of the $19^{\text {th }}$ century, as Mosse's book reveals, a more dynamic picture of German national festivals emerges. This was the time of German unification, which brought dramatic changes to German social structure. According to Mosse, Wilhelminian patriotic festivals, like the Sedanfest introduced in 1871, were failures (ibid.: 91). Blame for these failures is mainly attached to the festivals' producers. In Mosse's words: 'The Wilhelminian festivities never broke through to become genuine rites with a liturgy that made room for popular participation' (ibid.: 92, italics mine). The 'people were excluded from active participation' (ibid.: 91); 'they watched from the sidelines' (ibid.: 92); and the festivals 'reduc[ed] the public to the status of spectators' (ibid.: 93).

For Mosse, the fact that the masses are now excluded (again put in the passive form!) from active participation in these 'rituals' presents a serious problem from a Durkheimian viewpoint. This perspective is nicely summarised by Paul Connerton, who claims that 'to enact a rite is always, in some sense, to assent to its meaning' (1989: 44). Mosse, as we have seen, clearly subscribes to this view. One of its 
consequences could be that the content of these rites is of no importance. It is not 'what' is performed, but 'how' it is performed that matters. If the rite has a clear liturgy and the masses actively engage in enacting it, the message is not important. Liturgies can therefore be performed in a language that the participating masses do not even understand. This conclusion originates from Mosse's, and not only Mosse's, treatment of the public. They can be excluded, but are rarely seen as agents that exclude themselves from such ceremonies. They are reactive objects rather than reflexive agents.

When Mosse discusses the establishment's attempt to imbue the values of 'bourgeois pleasantness', he touches, in my view, on one of the most crucial aspects of the role of national ceremonies in the process of nation-formation. Unfortunately, due probably to his focus on the German case study and his Durkhemian approach, he fails to give it the attention it deserves. Mosse overlooks the fact that:

1. there is an obvious distinction between the active participants in a festival/ceremony and the spectators.

2. the 'masses' are capable of critically assessing the 'liturgy' and its meanings, a process that includes reflecting on their own experiences.

3. the 'masses' are capable of identifying and interpreting the intentions of the producers of these festivals and ceremonies in their own individual ways and based on their own biographical memories.

4. only pre-modern, simple, and small communities may have achieved the level of homogeneity in sharing both the meanings of performed 'liturgy' and the interpretations of the producers' intentions. 
As Randall Collins argues, a Durkheimian 'collective conscience', where the whole group subscribes to the projected meanings and interpretations, 'can exist in little pockets rather than as one huge sky covering everybody in the society' (2004: 15). While Durkheim, in his explanation of the role of rituals in a society, was explicitly talking about so-called traditional, tribal societies of small groups, Mosse and many other theorists of nationalism choose not to take into account that national ceremonies are a product of modernity. It is not only the changing structure of society that defines the modern era. Neither is it only the altered nature of cultural and political elites. Modernity's emerging sets of ideas and ideologies have altered the characteristics of Mosse's 'masses' as well.

In Social Performance Jeffrey Alexander argues (2006: 30) that

If there is one cultural quality that marks the earliest forms of human social organization, it is the centrality of rituals ... if there is one cultural quality that differentiates more contemporary, large-scale, and complex social organizations from earlier forms, it is that the centrality of such ritual processes has been displaced.

This displacement of rituals is what Weber calls 'the movement from charisma to routinization and from traditional to value and goal-rational society' (ibid.). Modern societies are no longer characterised by the unquestioned acceptance of values imposed from the top-down. They are societies of negotiation and reflexivity. 'Rather than being organized primarily through rituals that affirm metaphysical and consensual beliefs', Alexander adds, 'contemporary societies have opened themselves to processes of negotiations and reflexivity about means and ends, with 
the result that conflict, disappointment, and feelings of bad faith are at least as common as integration, affirmation, and the energizing of the collective spirit' (ibid.). In this passage Alexander implicitly assigns specific forms and functions to rituals. Rituals affirm beliefs and integrate and energize the collective spirit. Performances do not. Since this distinction between rituals and performances is left unspecified in Alexander's work, it is necessary to dedicate some space to its clarification. Although this paper does not require a thorough examination of the history of theorizing rituals or performances, crucial relations, similarities and differences between the phenomena must be outlined. ${ }^{1}$

\section{Rituals and Performances}

In the quote above, Alexander implies that rituals and performances are distinctive phenomena, where in historical progression one is replaced by another. Yet a brief overview of the main literature of performance studies indicates that Alexander adopts a rather narrow view of performances. For Richard Schechner (1988), one of the leading theorists of performances, ritual - beside play, games, sports, and theatre/dance/music - is just one genre of performance. For Schechner, these two concepts do not stand in a direct opposition. All rituals are performances, but not all performances are rituals. All performances share certain basic qualities: (1) they are enacted in a special ordering time, (2) they all attach a special value to objects imbued with values, (3) they are all non-productive in terms of goods - 'standing quite consciously outside “ordinary” life' (Huizinga, quoted in Schechner, 1988: 11); and (4) all of them are framed within a certain set of rules, conventions or traditions (Schechner, 1988: 10-13).

\footnotetext{
${ }^{1}$ For more about the main theories of rituals and performances, see Marvin (1996), Schechner (1988 and 2002), Turner (1969 and 1982).
} 
These different genres of performances Schechner places on a continuum where ritual-like performances are at one pole, and theatre-like ones on the other. 'Whether one calls a specific performance "ritual" or "theatre" depends mostly on context and function' (ibid.: 130). Context is defined by where, by whom and under which circumstances a performance is performed. Yet, it seems that for Schechner the crucial factor for defining the genre of a performance is its function. He states: 'If the performance's purpose is to effect transformations - to be efficacious - ... the performance is a ritual' (ibid.). Where the function of the performance is entertainment, the performance is theatre.

Schechner's emphasis on the function of a performance as the crucial factor in defining its genre poses a considerable problem for any analysis since, following this logic, genres can only be established ex post facto. If a performance achieves a transformation of participants' status or identity, we can call it ritual. If a performance manages to entertain, but not to transform, it is closer to theatre. Unless the function of a performance is determined by the intentions of the producers, I argue that defining the genre of performances in such a way wrongly assumes that performances would have the same impact on all those present at the performance. In the age of complex, reflexive societies, the effects of a performance are not so clearly identifiable. Performers do not necessarily define their performance. Rather, we must look to those for whom the performance is enacted.

Contrasting efficacy/ritual with entertainment/theatre, Schechner points to their crucial differences regarding interactions between those who stage a performance and 
those for whom a performance is staged. He states that the audience in a ritual participates, while those in a theatre watch. Rituals' audiences believe, while those of theatres appreciate. Criticism in rituals is discouraged. In theatre it flourishes (ibid.). Alexander acknowledges the crucial role that the audience plays in defining a performance. He describes rituals as 'episodes of repeated and simplified cultural communication in which the direct partners to a social interaction, and those observing it, share a mutual belief in the descriptive and prescriptive validity of communication's symbolic content and accept the authenticity of one another's intention' (2006: 29. emphasis added). The crucial element that makes this type of social interaction a ritual is not only its comparatively stable structure and repetitive occurrence. Rather, it is through mutual 'understanding of intention and content' and 'intrinsic validity of the interaction that rituals have their effect and affect' (ibid.).

Both Alexander and Schechner indicate that in a ritual there are no observers, only active participants, all 'believers'. All parties, those on the stage and those before it, play a role in a ritual. This is the central difference between ritual and all other genres of performances. Ritual 'is legitimate as long as no one watches it from a window, or from a special platform, otherwise it becomes a parade, a ballet in chains or a brass band.' (Shklovsky 1923: 61 cited in Fisher-Lichte, 2005: 111).

Following these arguments, it is important to emphasize that the routinization of a performance does not make it a ritual, though it may be a ritual-like performance. Literature on nations and nationalism tends to uncritically adopt the term ritual for all performances officially or unofficially defined as national. Indeed, labelling a performance as a ritual saves us from a painstaking examination of the audience's 
reaction to the performance and by default implies its sacralisation by the collective. It allows us to assume that today, as much as in the tribal societies, these performances imbue the members of the community with a specific identity. As Schechner (ibid.: 7) warns us: '[s]ometimes rituals, games, sports, and the aesthetic genres ... [and, indeed, national ceremonies] are merged so that it is impossible to call the activity by any one limiting name'. Hence, a non-limiting name, like 'performance', could save us from ritualizing the all repetitive social events, whether they might transform or entertain us.

In her examination of political theatre, Erika Fischer-Lichte (2005) demonstrates that all performance genres have a transformative capacity. All, including national ceremonies and political rallies, have a capacity to bind performers and their audiences together in physical and emotional interaction. If such binding occurs, Alexander declares the performance to be a success. For him, audiences of a successful performance will identify with actors, and cultural scripts will achieve verisimilitude through effective mise-en-scène. In similar manner, Fisher-Lichte (2005: 54) claims that 'it is the atmosphere which binds performers and spectators together', where 'the performance is carried out as a mutual resonance between the rhythm of the actors and spectators'. Only successful performances might be seen by some as 'ritual-like' events, where they achieve cultural extension to the audience and the audience psychologically identifies with the performance. In Alexander's words, the performance is then re-fused. A performance fails when this re-linking is incomplete, the elements of performance remain apart, and social action seems artificial by failing to persuade. Such a performance is de-fused. 
In Alexander's framework, the success of performances is measured, and can only be measured, through the response of the audience. Some analyses of national ceremonies and festivals, especially in theories of nationalism, are content with identifying who the performers are and which texts are to be performed, reconstructing the meaning of a performance through an analysis of its texts, which are containers for specific, fixed meanings. In such analyses, the reception of the audience is merely assumed. Only then does it become relevant to ask whether a text is pure invention or is a symbol of national continuity, identifying it as a mere collection of memories or a collective memory.

The relevant criteria for the evaluation of a national ceremony's success or failure are already indicated in Mosse's work (1975). When Mosse writes about the festivals of the Second German Empire, he notes how these festivals were 'in danger of becoming artificial creations' (ibid.: 90) and how '[p] eople became bored with these symbols of national worship' (ibid.: 97). Only with the noticeable failure of these festivals does Mosse pay some attention to 'political and class divisions among the population' (ibid.: 98).

For Alexander, a successful performance manages to achieve an emotional connection between the audience, the actors, and text. For Fisher-Lichte, a successful performance creates a shared experience of emotions or bodily sensations. Rather than attempting to elaborate on these emotions myself, I'll leave it to someone who apparently had many conflicting ones - Frederick Nietzsche. The eighth chapter of Beyond Good and Evil, published in 1886 and entitled Peoples and Fatherlands ([1886] 2000: 363), begins: 'I heard once again for the first time Richard Wagner's 
overture to the Meistersinger'. Even those who, for whatever reasons, cannot stand Wagner could, just from this sentence, easily conclude that the performance was a success for Nietzsche. In the description that follows, Nietzsche reveals his emotional connection with the performance - with the performed music, with the performers, with the composer, and with the entire mise-en-scène. He says:
Altogether, no beauty, nothing of southern and subtle brightness of the sky, nothing of gracefulness, no dance, scarcely any will to logic; even a certain clumsiness that is actually stressed, as if the artist wished to say to us, "that is part of my intention", cumbersome drapery, something capricious, barbarian, and solemn, a flurry of erudite preciousness and lace ... (ibid.: 363)

Immediately after these signs of psychological identification with the performers and the performed, Nietzsche demonstrates the level of cultural extension achieved where cultural background becomes one with the foreground text:

... something German in the best and worst senses of the word, something manifold, formless, and inexhaustible in a German way; a certain German powerfulness and overfulness of the soul which is not afraid of hiding behind the refinements of decay - which perhaps really feels most at home there; a truly genuine token of the German soul which is at the same time young and superannuated, overly mellow and still overrich in future... (ibid.).

\begin{abstract}
Alexander would infer that this performance of Wagner's Maistersinger was successful for Nietzsche because Nietzsche saw it as authentic. Alexander states: 'Performances in complex societies seek to overcome fragmentation by creating flow and achieving authenticity. They try to recover a momentary experience of ritual, to
\end{abstract}


eliminate or to negate the effects of social and cultural de-fusion' (2006: 56, emphasis added). But while performers' intentions might be visible and understandable, the audience is the ultimate judge of a performances' verisimilitude. For Alexander, though, the notion of authenticity is unproblematic. In everyday life, 'authenticity is thematized by such questions as whether a person is "real" - straightforward, truthful and sincere' (2006: 55). Yet, in the long months since I began trying to elicit some ideas from my colleagues and friends, I soon realised that we do not share the same definition of authenticity. Worse, we do not attach the same labels to material objects or people. I felt much better when I discovered that many of the most prominent works on authenticity are equally reluctant to fix the term's meaning. And with good reason.

\section{Authentic Nations}

In everyday life, the term authenticity is attached to material things as much as it is to one's self; to individuals as to collectives; to specific social interactions as to whole cultures. In their attempts to explain the notion, authors mirror it with other expressions: “autonomy”, "sincerity”, “individuality," "self-development," “selfrealization", "self-possession", but also with phrases such as "your own thing”, "true self”, "real me”, “owning myself", or something that is "genuine”, “original”, "trustworthy", "legitimate", "unaltered". Marshall Berman, in his Politics of Authenticity (1971: xiii), notices how 'our vocabulary overflows with expressions which express a persistent and intense concern with being oneself'.

Regardless of the definition to which we adhere, there is practically no person who would not be able to apply the notion of authenticity to some object, person, culture or 
group. Today, we generally attach considerable significance and value to 'being authentic'. Just look for references in so-called self-help books and at week-long courses which will, for no more than a couple of hundred pounds, help you find 'your true self'. The fact that authenticity can be expressed in pounds or in any other currency is not new. After all, those who can afford to do so will proudly exhibit collections of authentic things on their walls.

Though, for many of us, authenticity implies some level of connection with 'old' and 'original' things of the past, and hence things of value, the concept of authenticity is a product of modernity. Just as with the concept of nationalism itself, the term authenticity enters our vocabulary (indeed, mainly in Western civilisation) with the break up of the so-called traditional world. There is no need to elaborate on the genesis of the term, since many authors have done so in succinct and thorough ways, including Lionel Trilling in his Sincerity and Authenticity (1971), Marshall Berman in his Politics of Authenticity (1971), Charles Taylor in The Ethics of Authenticity (1991), and Jacob Golomb in In Search of Authenticity (1995).

Reading these works, it is difficult to find a term with a more controversial existence; so accepted in everyday social and private lives, yet so contested and controversial in the meta-life of ideas. The literature on authenticity that I could access, and indeed digest, can be organised according to the ways in which their authors examine issues of personal authenticity or the authenticity of social groups, their cultures and cultural objects. While personal authenticity is mainly examined in existentialist and antiexistentialist literature, disciplines such as cultural studies and studies of art, folklore and tourism opt to examine the authenticity of cultures and cultural objects. At first, it 
seems that these two levels of discussion have little in common beyond their use of the term itself. While 'cultural studies' find the origin of the word in the works of Rousseau and Herder, works on existentialism find it, as Golomb calls it, in a 'desperate journal entry, dated 1 August, 1835, of a 22-year-old Dane'. Here Kierkegaard wrote: 'the thing is to find a truth which is true for $m e$, to find the idea for which I can live and die' (cited in Golomb, 1995: 33). While almost all existentialists claim that 'any positive definition of authenticity would be selfnullifying', or, as Sartre claims, 'beyond the domain of objective language' (ibid.: 7), those from cultural studies aim to determine 'a more complete and objective concept of authenticity' (Lindholm, 2008: 2). While existentialists are seen as individualists who apparently imply that all normativity is validated 'from within', culturalists sometimes see whole social groups and their interactions as authentic. While existentialist writers aim to 'evoke in their readers the pathos of authenticity' by using literary forms full of irony (Golomb, 1995: 19), culturalists see it as a 'thing' that can be studied using objective research methods. Yet, despite their differences, both groups are engaged in the search for authenticity, one insisting that it can be found only within ourselves, the other looking for it in the objective, 'really real' world.

Most existentialist writers insist that there is no objective definition of authenticity, since each individual has to find his/her own self. They try to convince us that the main question is not 'what' a true expression of authenticity is, but 'how' one reaches that authenticity. In their works, existentialists set usually fictional examples of heroes and anti-heroes in extreme situations, though these are not given as prescriptions. There are innumerable ways in which we can construct our true selves in a situation where no inner or outer criteria for validity exist, and each one of us is supposed to 
find our own path. As Nietzsche's Zarathustra says: 'if you want to climb high, use your own legs'. But, as Regina Bendix notes, '[a] very thin line separates the desire for individual authenticity and the calling to convince others of correctness of a particular rendering or localisation of the authentic' (Bendix, 1997, 20).

Nationalism and the concept of authenticity lead intertwined lives. Even authors who manage to identify some forms of nations in the pre-modern world would see nationalism, be it an ideology or a political movement, as a modern phenomenon. The emergence of nationalism is usually framed within a story of a rapidly changing structural world - of industrialisation, migration from rural to urban centres, capitalist economy, even population density - and/or the dramatic implications of a newly emerging revolution within the world of ideas - from the omnipotent notion of reason and progress, through the death of god, to the triumvirate of brotherhood, equality and liberty that were firmly placed on the shoulders of popular sovereignty. Within these worlds the ideology of nationalism emerges as a schizophrenic Janus - pulled between the nostalgia for the past and a longing for a better future, but directed and produced by the present.

\begin{abstract}
Almost all of the aforementioned authors claim a similar birthdate for authenticity, though, depending on the author, its fathers vary. It emerged in the transitional period between the breakdown of simpler traditional societies and the emergence of complex ones. For Charles Taylor, this period is marked by 'the massive subjective turn of modern culture' which demands that we follow 'a voice of nature within us' (ibid.: 26-7). A crucial turn in articulating the notion of authenticity comes with the writings of Rousseau and Herder. According to Trilling 'From Rousseau we learned that what
\end{abstract}


destroys our authenticity is society - our sentiment of being depends upon the opinion of other people' (Trilling, 1971: 93). Rousseau's work could be seen as a programme for authenticity. It is a reaction against the 'corrupted ancient regime, the trenchant indictments of Christian fanaticism and intolerance, [and] cultural relativism' (Berman 1970: 5). This programme was 'attempting to give dignity to [individuals], liberating [them] from the superstructure of society in order to give [them] back to society pure and uncontaminated' (Cocchiare cited in Bendix 1996: 16). In Rousseau's writings we learn that, once we are purified of the influence of families, schools, churches and the contaminating influence of others, we can discover the original virtue of every human being (ibid.). For Rousseau, the embodiment of authentic existence can be found in the noble savage - the human being uncorrupted by the evils of modern civilization, who lives in and with nature. From that point on, Berman (1970: xvii) argues, '[t]he search for authenticity ... is bound up with a radical rejection of things as they are'. For Charles Taylor (1991: 25) authenticity is 'a child of the Romantic period, which was critical of disengaged rationality and of human atomism that didn't recognize the ties of community'. Here, the issue of authenticity is mainly seen as an issue of morality. At the time of the death of god, as Nietzsche called it, an inner voice was sought that would tell us how to act morally. As Taylor puts it: 'Being in touch with our moral feelings would matter here, as a means to the end of acting rightly' (1991: 26).

According to Taylor, Herder's main influence was his idea that 'each one of us has an original way of being human', or as Herder put it - has his or her own 'measure' (1991: 28). Herder was mainly concerned with the origin of language, which he found in the 'inventive nature of human beings' (Bendix 1996: 36). Revolting against the 
Enlightenment's all-pervasive rationality that subsumed the emotional, Herder saw artistic language as a means of legitimising this sentiment. The 'human being feels with reason and speaks while he thinks' (Herder quoted in Bendix 1996: 36). This, 'the language of nature' - one that expressed 'the highest thunderclaps of eloquence, the most powerful blows of the art in poetry, and the magic moments of action' (ibid.: 36-7) - is found in the expressive culture of native song, classical epics and folk poetry. The search for authentic culture is a search for expressions of the uncorrupted, pure human soul. At this point we stumble onto the familiar ground of German Romantic writers, especially in the ideological development of cultural nationalism. How is it possible that such apparently individualistic views, expressed in both Rousseau's and Herder's writings, and implied in the notion of individual authenticity, led toward the collectivizing impact of cultural nationalism?

When Berman discusses the meaning of authenticity - 'the notion of being oneself' he asks: '... isn't everyone himself already? ... Who or what else could he be?' (1975: xiv). The whole idea of authenticity, he continues, is seemingly tautological and paradoxical. For Rousseau, Herder and most existentialists, this paradox is embedded in the structure of the modern world. In their writings, the search for authenticity is a social act. In order for an individual to be authentic, it is necessary to change the society that forces that individual to live an inauthentic life in order to conform to dominant social roles and norms. 'This world, they say, represses, alienates, divides, denies, destroys the self' (Berman 19975: xiv). Hence, salvation for an individual leads in two ways - either to a complete retreat from the social or to an active engagement to change that world. German Romantics opted for the latter. As Regina Bendix says: 'Herder and Sturm und Drang romantics solidified the link 
between the search for personal, moral authenticity and its artistic expression and communication. For them, the verbal art of the peasantry became a means for humanity at large to get in touch with authenticity' (1996: 17). Already with the German Romantics, the notion of an authentic life became the leading social value. It is this emerging value system that conditions individual actions achievable through a painful engagement in self-reflection as much as through the creation of a nonconstraining, non-alienating social world. Berman calls it the 'politics of authenticity', projecting 'a dream of an ideal community in which individuality will not be subsumed and sacrificed, but fully developed and expressed' (1975, vii). He finds it in the politics of the German Romantics and as a 'point of departure for both liberal and socialist thought' (ibid., xv). We can find it in Marx and Engels' Communist Manifesto, and in the writings of John Stuart Mill. Yet, I would argue, the clearest expressions of this longing for an authentic life, usually detected in the primitive uncorrupted societies of the past, is found in ideologies of nationalism.

From its origins, the search for authenticity became part and parcel of nationalist ideology, based on the notion that somewhere deep within each of us lies the preexisting self (individual or collective). Unlike many existentialists (like Heidegger and Sartre) who argue that the search for authenticity is a creative process that produces an ever-changing self, authors from the French revolution to the German Romantics, from Schopenhauer to Marx, Ibsen, Nietzsche, the psychoanalysts, and most nationalist ideologists hold 'the firmly entrenched belief that beneath the appearance of every human phenomenon there lies concealed a discrepant actuality and that intellectual, practical, and (not least) moral advantage is to be gained by forcibly bringing it to light' (Trilling 1971). What Trilling calls an 'unmasking trend', 
the creators of nationalist ideologies call 'national awakening'. National awakening is not just the process of mobilizing any group of people. It is perceived as a process of unmasking the authentic collective soul that will determine national character and reveal the true path to a future where that soul can blossom. Nationalist ideologies seek to determine a single meaning of the authentic and offer a definition of "who we are', where their creators serve as authenticators of 'who we were'.

These quests for authentic expressions of the national soul are exemplified in many theories of nations and nationalism. Yet most of these, like the so-called constructivists and ethno-symbolists, focus their theories on what nationalists have apparently already found in their quests - material objects and narratives that become symbols of the nation and its authenticity. Both groups of theories imply, directly or indirectly, the significance of authenticity. Anthony Smith does it explicitly when he examines how 'an elective affinity drew nationalism to archaeology and vice versa' (2001: 441). He clearly states that 'the key to this affinity lay in the ideal of authenticity' where archaeological findings are seen as 'evidence' of national uniqueness, originality, and continuity (ibid.). While ethno-symbolism therefore attaches a great importance to the ethnic past that apparently authenticates the nation, Hobsbawm and Ranger (1983) try to demonstrate that these traditions can be invented or artificially created, and that some of them are just fakes. The disagreement between ethno-symbolists and constructivists is, in my view, based on false premises. Regardless of their differences, both groups objectify the notion of authenticity. Both groups of theories see the authentic in terms of the true and original, though original does not necessarily imply organic emergence. 
In the second part of Culture and Authenticity (2008), Lindholm offers examples of collective authenticity. These include stories of how Belizeans, after achieving independence, found their authentic dish in the so-called 'Royal Rat', just as Italians did in pasta and Indians in curry. It shows how rumba is proclaimed to be authentically Cuban, and how one can only see real tango in Argentina. Being seen as authentic by those within these nations and those outside of them has nothing to do with the fact that many of these national symbols are constructed, even invented. In order to prove the importance of historical cultural backgrounds to the process of nation-formation, ethno-symbolists, as opposed to constructivists, do not have to search for those symbols that are not invented. The power of a symbol is not derived from its origins, but from its accepted specificity and authenticity.

There are no such things as authentic nations - a nation with original, organic, unique material and textual evidence of continuity (even though these can be presented as such) - since there is no set of objective criteria for assessing authenticity. While authorship is one of the main criteria for authenticity in art, authorship of a national folksong is the sign of a fake. Hence the Ossian Scripts are Macpherson's and the Kalevala is 'ours'. Instead, there are only nations that are experienced as authentic.

Sartre believed that there is 'no entity that is an original, authentic self or ego, as Rousseau tended to believe' (Golomb 1995: 132). Authenticity, rather, is seen as a creative process. Authentic states [of individuals] are instantaneous, not permanent (ibid.). Hence, I cannot but agree with Regina Bendix (1996: 14) who states: After years of reading and thinking about what, if anything, could still be authentic, I saw authenticity at best as a quality of experience: the chills 
running down one's spine during musical performances, for instance, moments that may stir one to tears, laughter, elation - which on reflection crystallize into categories and in the process lose the immediacy that characterizes authenticity.

This brings us back to the importance of national ceremonies in the process of nationformation.

\section{Pursuing Authenticity}

Since many works on nationalism, including Mosse's, have extensively described both the texts that are performed and the characteristics of the performers, and have offered some reconstructions of their intentions, there is no need to engage in further discussion here. It suffices to say that the only intention on the part of performers that can always be assumed is their hope that the performance will have an intended effect on the audience. The performers of a national ceremony do not just hope that the targeted audience will understand and internalize the projected meaning of the act, which implies a cognitive reaction. The selection of the text performed and the whole mise-en-scène is primarily designed to provoke an emotional response from the audience. Following Alexander, I would argue that such emotional reaction will occur only when the audience perceives its experience as authentic.

Even this statement has its problems since the 'audience' might be seen as implying a fully homogenous community. As Randall Collins explains in Interaction Ritual Chains (2004), events like festivals and ceremonies should be observed as situations. That is, they are 'momentary encounters among human bodies charged up with 
emotions and consciousness because they have gone through chains of previous encounters' (ibid.: 3). Collins' theory argues against the view according to which individuals are constant while situations change. He explains, 'When human bodies are together in the same place, there is a physical attunement: currents of feeling, a sense of wariness or interest, a palpable change in the atmosphere. The bodies are paying attention to each other, whether at first there is any great conscious awareness of it or not' (ibid.: 34). In these constructed situations, the reaction of an audience is not only conditioned by the group itself, but also by how the performance is performed.

Through her analysis of political theatre and mass spectacles in the first half of the $20^{\text {th }}$ century in Russia, Germany and the USA, Erica Fisher-Lichte (2005) finds that these performances are characterized by (1) the occupation of the space by the masses; (2) the way a particular atmosphere functions; (3) the dynamic and energetic bodies moving through the whole space. These techniques, in her view, 'made it difficult to distinguish between actors and spectators ... they formed one mass (FisherLichte, 2005: 51). Even Alexander would call this performance a success. This performance, Fisher-Lichte argues, created an aesthetic community formed on the basis of shared experience, emotions and bodily sensations. Fisher-Lichte continues:

... it is a community which is not based on common beliefs and shared ideologies - not even on shared meanings; it can do without them. For it comes into being through performative means. As long as the performance lasts it is capable of establishing a bond between individuals who come from the most diverse biographical, social, ideological, religious, political backgrounds and remain individuals who have associations of their own and generate quite different 
meanings. The performance does not force them into a common confession; instead, it allows for shared experiences (ibid.: 58).

Yet, even when this temporary communal experience is created, Fisher-Lichte argues, we cannot assume that all of the spectators have experienced it: 'It seems to have been matter of pride for most critics that they resisted it' (ibid.: 52). The effect of a successful performance is 'ephemeral, unable to bring forth any kind of collective identity' (ibid.: 141). The formed community lasts as long as the performance itself, and is dissolved soon after the spectators leave the arena. As Schechner (1988: 128) tells us, 'All the transformations - aesthetical and social as well as actual - are temporary'.

Let us recall the moment when Nietzsche 'once again for the first time' heard Wagner's Meistersinger. Immediately after reading all that is truly German in that Wagner overture, he closes the chapter, pauses, and then opens another with this: We 'good Europeans' - we, too, know hours when we permit ourselves some hearty fatherlandishness, a plop and relapse into old loves and narrowness ... More ponderous spirits than we are may require more time to get over what with us takes only hours and in a few hours has run its course; some require half a year, others half a life, depending on the speed and power of their digestion and metabolism. Indeed, I could imagine dull and sluggish races who would require a half a century even in our rapidly moving Europe to overcome such atavistic attacks of fatherlandishness and soil addiction and to return to reason, meaning 'good Europeanism' ([1886] 2000: 364). 
In this passage, Nietzsche beautifully demonstrates the aftermath of an authentic experience. After such moments, we go home and, like Nietzsche a hundred years before, we reconstruct our experience. This is the moment in which emotions aroused by the performance subside, in which we apply our standard technique of categorisation and measure our new experiences against previous ones. It is a moment when a performance is perceived through the lenses of previously formed values, norms and beliefs. In some, this authentic experience might be categorised as national. In others, as with Nietzsche, it might be interpreted as a moment of weakness.

Only successful performances can be seen as ritual-like. In these situations, and only when the performance is seen as authentic - when the re-fusion between the performers, the text performed, its mise-en-scène and the audience occurs - can rituallike performances constitute objects, including nations, as sacred. But Collins (2004: 17) warns: 'if the ritual is not carried out for a time, the sacredness fades away'. This temporality of possible identification with a collective is not merely a cognitive construction. Successful performances, national ceremonies and festivals alike, are situations seen as processes 'by which shared emotions and intersubjective focus sweep individuals along by flooding their consciousness' (ibid.: 32). And '[w]hen the practices stop', Collins (ibid.: 37) continues, 'beliefs lose their emotional import, becoming mere memories, forms without substance, eventually dead and meaningless'. Hence, Fisher-Lichte (2005: 110-1) concludes that 'a performance is not a suitable means of manipulation' since there is no guarantee how the audience will react to the performance. But at the same time, 'the spectators cannot be regarded as innocent victims being manipulated by those who planned and prepared the 
performance' (ibid.) since, by their response, the audience contributes to the performance. In a short run, national ceremonies can give us authentic experiences of shared joy and elation, grief or solemnity. In a long run, national ceremonies can only give us memories around which we can reflect and negotiate our already existing sense of belonging.

\section{Concluding remarks}

As we learned from Ernest Gellner, all nations are described by their nationalist ideologies and perceived as authentic by their nationalist movements. Each of them faces no problem in filling, to invoke Mosse, a sacralised building with evidences of their 'true selves'. Indeed, if some could not claim authenticity on the basis of genealogy or history - that is, of their 'origin' - they are quite confident in expressing it on the basis of their 'content' - their identity or correspondence (Lindholm 2008: 2). Every nationalist ideology projects a picture of the 'nation's true self', whether it is labelled civic, ethnic, or anything in-between. All nationalisms, even those labelled as civic, tend to describe their authentic self as something that pre-exists the nation and has to be 'awakened'. As soon as a nation is defined in terms of any set of objective characteristics - be it language, a specific set of rights and duties, or even landscape - the prior existence of the authentic nation is assumed. That could explain why, regardless of the fact that some nations are seen as ancient and some as modern, some as organic and some as mechanical, some as reconstructed and some as invented, those that have survived have all manage to invoke passions among their members at crucial points in time. 
In my view, nationalism is the dominant form of the politics of authenticity. Every nationalist ideology is a prescription of authenticity. Yet, not all views of the authentic are collectivized. National ideologies are enacted in different forms, including national ceremonies. Their producers hope that through a performative act, their audiences will internalize the enacted prescription of the nation. But theorists of nations and nationalism should not conflate intentions with outcomes. Labelling every routinized national ceremony a 'ritual' hides the crucial and unpredictable dynamic between the performers and their audiences and masks as authentic that which is persistently authenticated. 
Bibliography:

ALEXANDER, JEFFREY 2006 'Cultural Pragmatics: Social performance between ritual and strategy', in Jeffrey Alexander et al (eds), Social Performance: Symbolic Action, Cultural Pragmatics, and Ritual, Cambridge: Cambridge University Press, pp. $29-90$

ADORNO, THEODORE 1973 The Jargon of Authenticity, London: Routledge BENDIX, REGINA 1996 In Search of Authenticity: The formation of folklore studies, Madison, WI: The University of Wisconsin Press BERMAN, MARSHALL 1970 The Politics of Authenticity: Radical Individualism and the Emergence of Modern Society, London: George Allen \& Unwin ltd CHENG, VINCENT J. 2004 Inauthentic: The Anxiety over Culture and Identity, New Brunswick, NJ: Rutgers University Press

COLLINS, RANDALL 2004 Interaction Ritual Chains, Princeton: Princeton University Press

CONNERTON, PAUL 1989 How Societies Remember, Cambridge: Cambridge University Press

EYERMAN, RON 2006 'Performing Opposition or, how Social Movements Move', in Jeffrey Alexander et al (eds) Social Performance: Symbolic Action, Cultural Pragmatics, and Ritual, Cambridge: Cambridge University Press, pp. 193-217 FERRARA, ALESSANDRO 1998 Reflective Authenticity: Rethinking the project of modernity, London: Routledge

FISCHER-LICHTE, ERICA 2005 Theatre, Sacrifice, Ritual: Exploring Forms of Political Theatre, London: Routledge

-- 2008 The Transformative Power of Performance: A New Aesthetics, London:

Routledge

GOLOMB, JACOB 1995 In Search of Authenticity: From Kierkegaard to Camus, London: Routledge

GUIGNON, CHARLES 2004 On Being Authentic, London: Routledge HOBSBAWM, ERIC and RANGER, TERENCE 1983 The Invention of Tradition, Cambridge: Cambridge University Press

LINDHOLM, CHARLES 2008 Culture and Authenticity, Oxford: Blackwell 
MOSSE, GEORGE L. 1975 The Nationalisation of Masses, New York: Howard Fertig

NIETZSCHE, FREDERICK 2000 'Beyond Good and Evil', in Walter Kaufmann (ed.) Basic Writings of Nietzsche, New York: The Modern Library, pp. 179-436 SCHECHNER, RICHARD 1988 Performance Theory, 2nd edn, London: Routledge -- 2002 Performance Studies: An Introduction, 2nd edn, London: Routledge SMITH, ANTHONY D. 2001 'Authenticity, Antiquity and Archaeology', Nations and Nationalism, vol. 7, no. 4, pp. 441-9

TAYLOR, CHARLES 1991 The Ethics of Authenticity, Cambridge, MA: Harvard University Press

TRILLING, LIONEL 1971 Sincerity and Authenticity, Cambridge, MA: Harvard University Press

TURNER, VICTOR 1969 The Ritual Process: Structure and Anti-Structure, New York: Aldine de Gruyter

-- 1982 From Ritual to Theatre: The Human Seriousness of Play, New York: PAJ Publications

GORDANA UZELAC is Senior Lecturer in the Department of Applied Social Sciences at London Metropolitan University.

ADDRESS: Department of Applied Social Sciences, London Metropolitan University, 62-66 Highbury Grove, London N5 2AD, UK. Email:

g.uzelac@londdonmet.ac.uk 